\title{
Influence of drying mode and feed per tooth rate on the fine dust creation in pine and beech sawing on a mini sash gang saw
}

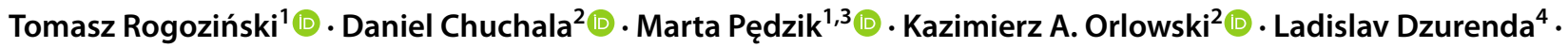 \\ Tomasz Muzinski ${ }^{5}$
}

Received: 17 April 2020 / Accepted: 3 October 2020 / Published online: 16 October 2020

(C) The Author(s) 2020

\begin{abstract}
The experimental results of the study focused on the effect of drying processes of modified air drying and warm air-steam mixture drying of pine and beech wood on the size of sawdust particles created in cutting using PRW-15M sash gang saw, are presented in the paper. Particle size analysis of dry sawdust was performed using two methods-sieving method and laser diffraction analysis. The results showed that the drying process did not affect the general particle size distribution of the sawdust, but the content of very fine dust particles in beech wood sawdust is many times higher when the beech wood was dried in the warm air-steam mixture drying process and sawn at a feed per tooth of $0.105 \mathrm{~mm}$.
\end{abstract}

\section{Introduction}

Industries of material processing and the use of natural waste to produce energy are the main sources of dust emissions (Wilnhammer et al. 2017). Dust produced during

Tomasz Rogoziński

tomasz.rogozinski@up.poznan.pl

Daniel Chuchala

daniel.chuchala@pg.edu.pl

Marta Pędzik

m_pedzik@itd.poznan.pl

Kazimierz A. Orlowski

kazimierz.orlowski@pg.edu.pl

Ladislav Dzurenda

ladislav.dzurenda@tuzvo.sk

1 Department of Furniture Design, Faculty of Wood Technology, Poznań University of Life Sciences, ul. Wojska Polskiego 38/42, 60-637 Poznań, Poland

2 Department of Manufacturing and Production Engineering, Faculty of Mechanical Engineering, Gdańsk University of Technology, Gdańsk, Poland

3 Wood-Based Products and Biocomposites Department, Łukasiewicz Research Network, Wood Technology Institute, Poznań, Poland

4 Department of Woodworking, Faculty of Wood Sciences and Technology, Technical University in Zvolen, Zvolen, Slovakia

5 HS Hydromech, Lublewo Gdańskie, Poland sharpening, sanding or polishing surfaces is the most harmful to human health (Tong et al. 2018). The properties of dust depend primarily on the species of the raw material that was processed. Wood dust is particularly harmful, especially the dust of hardwood species such as oak and beech, which are considered as carcinogenic. Beech wood is one of the most dangerous materials used in the production of furniture and other wood products (Baran and Teul 2007; Jacobsen et al. 2010). This is confirmed by the International Agency for Research on Cancer, which classified wood dust to group 1, i.e. to substances with proven carcinogenic effect for humans (IARC 2012). Dust particles smaller than $<10 \mu \mathrm{m}$ are considered to be particularly harmful to the respiratory system. Even particles smaller than $100 \mu \mathrm{m}$ remain dispersed in the air, and can easily settle in the eyes, nose, skin and even penetrate the respiratory system. Epidemiological studies have shown a causal relationship between the incidence of nasal and paranasal sinuses cancers and wood dust exposure of woodworking industry employees (Pakulska et al. 2017). Therefore, air dustiness resulting from mechanical wood processing is one of the most important problems occurring in woodworking industry.

In addition to the type and dimensions of the material, the amount of waste generated and the content of fine dust particles is also influenced by the processing method, type of tool, the sharpness of cutting tools and technological parameters of the process, i.e. feed per tooth (Dzurenda and Kučerka 2005; Dzurenda et al. 2006; Očkajová et al. 2006, 2014, 2016; Hlásková et al. 2015, 2016; Mračková 
et al. 2016; Pałubicki and Rogoziński 2016). Bejlo-Lučič et al. (2005) compared the particle sizes resulting from the processing of wood and wood-based materials on seven different machines: a belt sander, manual belt sander, band saw, drill, circular saw, multi-circular saw and a four-side planer. By far the largest amount of harmful dust $<100 \mu \mathrm{m}$ is generated on sanding workstations compared to the results of other woodworking processes. Wood dust containing more than $90 \%$ of the particles with size $\leq 80 \mu \mathrm{m}$ is generated when grinding hardwood. Therefore, it is considered as one of the most dangerous to health and safety (Očkajová et al. 2018). CNC milling is another method of woodworking associated with the risk of dust. The milling process on the CNC machining center produces dust particles with size $<125 \mu \mathrm{m}$ in an amount of $1.4 \%$ for beech wood, $1.95 \%$ for oak and 3.8\% for softwood, while dust particles $<32 \mu \mathrm{m}$ have not been determined by the sieve analysis (Kminiak and Banski 2019).

Recently, much attention has been paid to studies on the influence of high temperature on the formation of fine dust during the machining of wood that has been thermally modified or dried. Kminiak and Dzurenda (2019) investigated the effect of heat treatment on changing the particle size of maple wood chips created in milling. Size analysis showed that more than $2 / 3$ of the chips created were a fraction with a particle size above $1 \mathrm{~mm}$. Inhalable dust particles smaller than $125 \mu \mathrm{m}$ did not exceed 2.5\%. Kučerka and Očkajová (2018) have done thermal modification of oak and spruce wood in accordance with ThermoWood technology. From the analysis of the dust obtained as a result of sanding modified wood, they showed that the proportion of dust fraction $\leq 80 \mu \mathrm{m}$ obtained in these experiments is comparable with the results of natural wood (Očkajová and Kučerka 2017; Dzurenda and Očkajová 2003). On this basis, it was concluded that the content of fine dust fraction decreases as the temperature increases. This means that the thermal treatment of wood does not have negative impact on the dustiness in the working environment.

On the other hand, Dzurenda et al. (2010) and Dzurenda and Orlowski (2011) indicated that sawdust formed during sawing of thermally modified oak and ash wood on the PRW-15M sash gang sawing machine using two rates of feed per tooth, has the fraction of particles in the size range $32-125 \mu \mathrm{m}$ slightly smaller than the unmodified oak and ash wood. Similar dependencies were observed by Očkajová et al. (2020) for thermally modified oak and spruce wood processed at $160{ }^{\circ} \mathrm{C}$ using the milling and sanding processes. Dzurenda and Kučerka (2005) performed a comparative analysis of dry and wet spruce sawdust and found that as a result of hot air drying, the coarse fraction $(125-1000 \mu \mathrm{m})$ increases by $7 \%$ and the fine fraction $\leq 125 \mu \mathrm{m}$ by $6.2 \%$. On the other hand, Orlowski et al. (2019) indicated that sawing pine and beech wood, regardless of the drying method, mainly produces sawdust with the size $<500 \mu \mathrm{m}$. Sawing beech wood dried with a mixture of warm air and steam at $105{ }^{\circ} \mathrm{C}$ causes an increase in the content of fine dust compared to wood dried in air. Based on particle size analyzes of sawdust generated from pine and beech wood processed on a sash gang saw, no fraction $<32 \mu \mathrm{m}$ was found. The results of these studies are not conclusive. They were obtained by applying sieve analysis. However, this is an unreliable method for very fine wood dust (Rogoziński and Očkajová 2013). Therefore, it was decided to investigate the influence of drying method of various wood species on the content of fine dust in sawdust using two complementary methods of particle size analysis.

\section{Materials and methods}

\subsection{Materials}

The investigation was carried out for samples of pine wood (Pinus sylvestris L.) and beech wood (Fagus sylvatica L.) originating from the Baltic Natural Forest Region (PL) (the Pomeranian District, Poland). The wood specimens used in the sawing experiments were prepared as blocks in dimensions of $\mathrm{W}($ Width $)=60 \mathrm{~mm} \times \mathrm{Hp}($ Height $)=60 \mathrm{~mm} \times \mathrm{Lp}$ (Length) $=500 \mathrm{~mm}$ in the sawmill PHU Drew-Met, Kiełpino, Poland. Samples of beech wood were marked as $\mathrm{BH}$, and samples of pine wood were indicated as PN. Examined samples were dried with different modes in industrial and laboratory conditions.

\subsection{Drying processes}

\subsubsection{Warm air-steam mixture drying process}

The drying process was conducted in an experimental semi-industrial kiln that was designed by employees of Gdansk University of Technology and manufactured by ASM Elektronik CLP, Szczaniec, Poland. The mentioned kiln is located at the Gdansk University of Technology. The methodologies of the experimental warm air-steam mixture drying process were described in detail by Baranski et al. (2017), Klement et al. (2018) and Baranski (2018). The drying process was carried out as a two-stage drying process and supervised by a control system. In the first stage, the drying medium temperature in the drying kiln was increased to $65^{\circ} \mathrm{C}$ and in the second stage to $80^{\circ} \mathrm{C}$. The final moisture content was obtained at around $10 \%$. Samples of wood dried in the warm air-steam mixture drying process were additionally marked with $\mathrm{S}$. 


\subsubsection{The modified air-drying process}

This process was conducted outside the workshop, at the Campus of the Gdansk University of Technology (Gdansk, Poland). The samples were stored under the sloped roof to keep from rain. Humidity and temperature were variable and dependent on weather conditions. At the end of the first process stage, the moisture content in dried material was approximately $16 \%$. The second stage of the modified airdrying process was the conditioning of wood samples in a laboratory room (GUT laboratory), where thermal-flow conditions, such as temperature and air velocity, ensured reaching the final value of moisture content of around $10 \%$. This modification allowed to receive values of moisture content similar to values obtained from other analyzed drying processes. Samples of wood dried in the modified air-drying process were marked with A.

\subsection{Sash gang saw and saw blade}

Cutting tests were conducted on the sash gang saw PRW15M (a prototype designed at the Department of Manufacturing Engineering and Automation. GUT, PL; manufactured by REMA-Reszel, PL) with a hybrid dynamically balanced driving system and elliptical teeth trajectory movement, as described by Wasielewski and Orlowski (2002). The sash gang saw and saw blade settings are shown in Table 1. Samples of wood, which have been sawn at $f_{z 1}$, were marked F1, and samples of wood, sawn at $f_{z 2}$ were marked F2.
The re-sawing methodology was described in the work by Orlowski et al. (2019), in which the only varying cutting parameter was feed speed, which was applied at two levels: $v_{f 1} \approx 0.9 \mathrm{~m} \mathrm{~min}^{-1}$ and $v_{f 2} \approx 1.72 \mathrm{~m} \mathrm{~min}^{-1}$. This corresponds to a feed per tooth $\left(f_{z}\right)$ of $\sim 0.105 \mathrm{~mm}$ and $\sim 0.2 \mathrm{~mm}$, respectively (Table 1). The actual value of the feed per tooth was calculated based on the sawing time taken from the plots of time changes of electrical power consumption (Fig. 1). The mean value of feed per tooth for a sash gang saw is calculated as:

$f_{z}=\frac{1000 \cdot v_{f} \cdot P}{n_{R P} \cdot H_{R P}}$

where: $n_{\mathrm{RP}}$ is stroke number of the frame in $\min ^{-1}, H_{\mathrm{RP}}$ is stroke of the frame in $\mathrm{mm}, P$ is a tooth pitch in $\mathrm{mm}$, and $v_{\mathrm{f}}$ in $\mathrm{m} \mathrm{min}^{-1}$ is calculated as:

$v_{f}=\frac{60 \cdot L_{p}}{t_{c}}$

where: $L_{\mathrm{p}}$ is length of the sample in $\mathrm{m}$ and $t_{\mathrm{c}}$ is the real cutting time in s, taken from the plot, (Fig. 1).

\subsection{Wood dust particle size analysis}

Determination of the content of the smallest dust particles in sawdust was carried out in accordance with the methodology previously described by Rogoziński et al. (2015, 2017), Hlásková et al. (2016), and Piernik et al. (2019). This methodology contains two complementary methods to determine
Table 1 Sash gang saw and saw blade settings for performed cutting tests

\begin{tabular}{llll}
\hline Name of parameter & Symbol & Value & Unit \\
\hline Machine tool setting & & & \\
Number of strokes of saw frame per min & $n_{F}$ & 685 & $\mathrm{spm}$ \\
Saw frame stroke & $H_{F}$ & 162 & $\mathrm{~mm}$ \\
Number of saws in the gang & $m$ & 5 & - \\
Average cutting speed & $v_{c}$ & 3.69 & $\mathrm{~m} \mathrm{~s}^{-1}$ \\
Feed speed & $v_{f 1}$ & $\sim 0.9$ & $\mathrm{~m} \mathrm{~min}^{-1}$ \\
& $v_{f 2}$ & $\sim 1.72$ & $\mathrm{~m} \mathrm{~min}^{-1}$ \\
Feed per tooth & $f_{z 1}$ & $\sim 0.105$ & $\mathrm{~mm}$ \\
& $f_{z 2}$ & $\sim 0.202$ & $\mathrm{~mm}$ \\
Tool setting & & & - \\
The sharp saw blades with stellite tipped teeth & - & - & $\mathrm{mm}$ \\
Overall set (kerf width) & $S_{t}$ & 2 & $\mathrm{~mm}$ \\
Saw blade thickness & $s$ & 0.9 & $\mathrm{~mm}$ \\
Free length of the saw blade & $L_{0}$ & 318 & $\mathrm{~mm}$ \\
Blade width & $b$ & 30 & $\mathrm{~mm}$ \\
Tooth pitch & $P$ & 13 & $\circ$ \\
Tool side rake angle & $\gamma_{f}$ & 9 & $\circ$ \\
Tool side clearance & $\alpha_{f}$ & 14 & $\mathrm{MPa}$ \\
Tension stresses of saws in the gang & $\sigma_{\mathrm{N}}$ & 300 & \\
\hline
\end{tabular}


Fig. 1 Time changes in electrical power consumption while sawing at two levels of feed speed $v_{\mathrm{f} 1}$ and $v_{\mathrm{f} 2}$ of beech samples BH-A-F1 and BH-A-F2, which were dried in the experimental kiln at the GUT

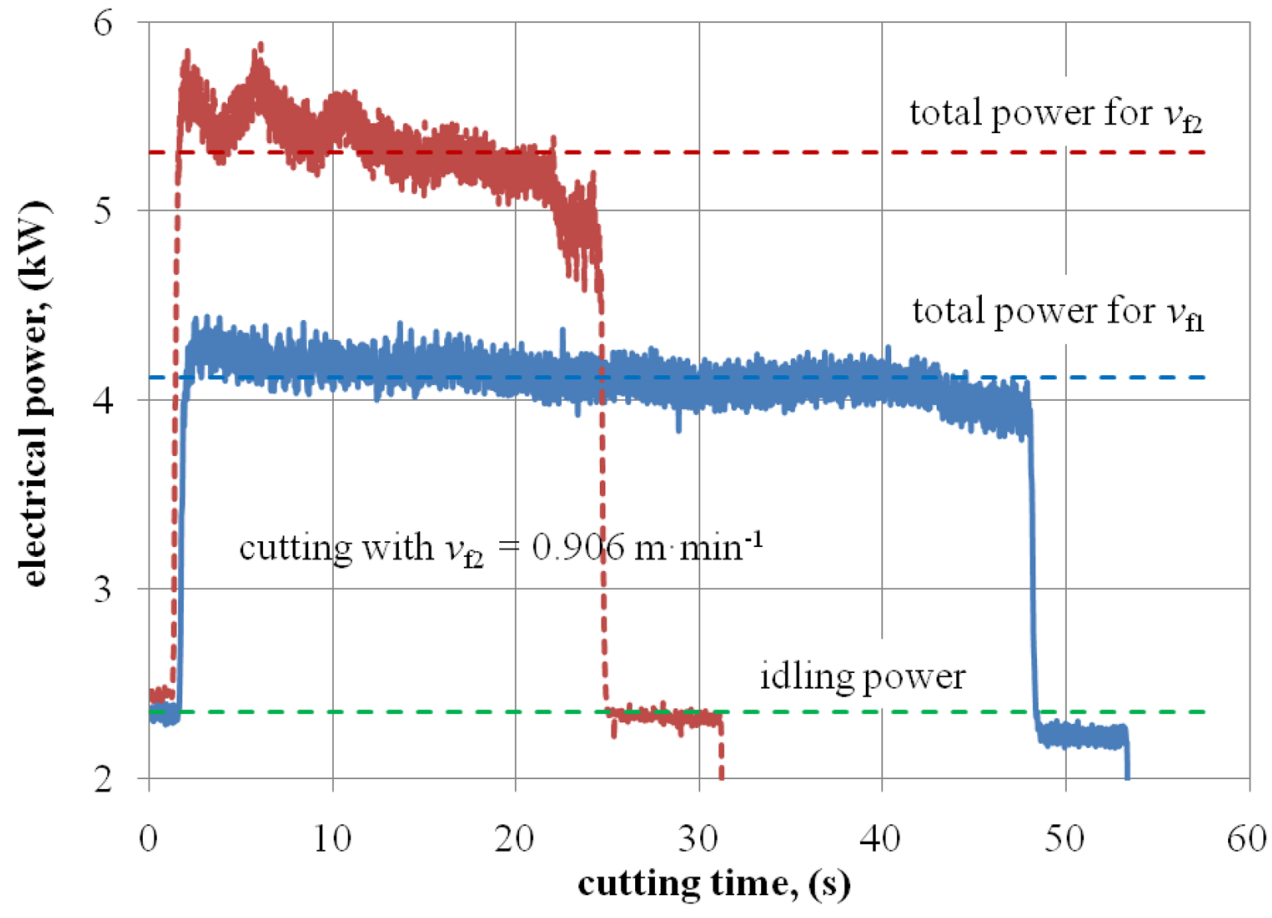

particle size distributions of dust. There are sieving and laser light scattering. The set of sieves with standardized mesh sizes of $2,1,0.5,0.25,0.125 \mathrm{~mm}$ was used, and the particle mean diameter was calculated as follows:

$\bar{x}=\frac{\sum_{i=1}^{n}\left(x_{i} \cdot q_{3 i}\right)}{N}$

where: $q_{3 i}$ is the density distribution by mass, unitless, $x_{i}$ is the average value of particle size class in $\mu \mathrm{m}, n$ is the number of particle size classes, $N$ is the the sum of the distribution by mass, unitless.

The standard deviation was calculated as:

$\sigma=\sqrt{\frac{\sum_{i=1}^{n}\left(x_{i}-\bar{x}\right) \cdot q_{3 i}}{n-1}}$

Laser particle sizer Analysette 22 Microtec Plus (Fritsch. Germany) with a measuring range of $0.08-2000 \mu \mathrm{m}$ was used for determination of the mass content of the finest particles in the whole mass of sawdust. Three particle sizes of $2.5,4$ and $10 \mu \mathrm{m}$ were used to estimate the concentration of very fine particles in the whole mass of sawdust.

\section{Results}

The results of the sieve analysis of the obtained sawdust are presented in Figs. 2 and 3. The arithmetic mean of the particle diameter and standard deviation were calculated based on the distributions shown there. The results of calculating these statistical parameters are presented in Table 2. A comparison of mean particle diameters of sawdust generated during sawing at two feed speeds indicates, to some extent, that sawing at a lower feed per tooth value results in smaller sized waste. It did not occur only in beech wood dried in the modified air-drying process.

The drying method does not affect the particle mean diameter of sawdust created when sawing at a feed per tooth of $0.202 \mathrm{~mm}$. In the case of sawing at a feed per tooth of $0.105 \mathrm{~mm}$, there was some variation in the value of the mean diameter of the particles, nevertheless, it is difficult to find any relationship based on the sieve analysis.

Comparing the cumulative distribution curves and the average dimension of sawdust by the type of wood species, it can be stated that generally beech sawdust is finer. In the case of pine wood, the smallest sawdust particles (mean particle diameter $550.3 \mu \mathrm{m}$ ) were formed from wood dried in the modified air drying process while sawing with lower feed speed. The curve corresponding to this sawdust is shifted to the left of the diagram scale (Fig. 2). Generally, the smallest mean particle diameter $(489.9 \mu \mathrm{m})$ was measured for sawdust from beech wood dried in warm air-steam mixture drying process sawn at a slower feed speed. The cumulative distribution curve of this sawdust is hence located on the graph in the smaller particle size range (Fig. 3). This phenomenon may be associated with differences in the values of material properties, such as fracture toughness, that were shown by Chuchala et al. (2020) for beech wood airdried and using a warm air-steam mixture drying process. 
Fig. 2 Particle size distributions of pine wood dust-by sieve analysis method as a function of both drying method and feed per tooth
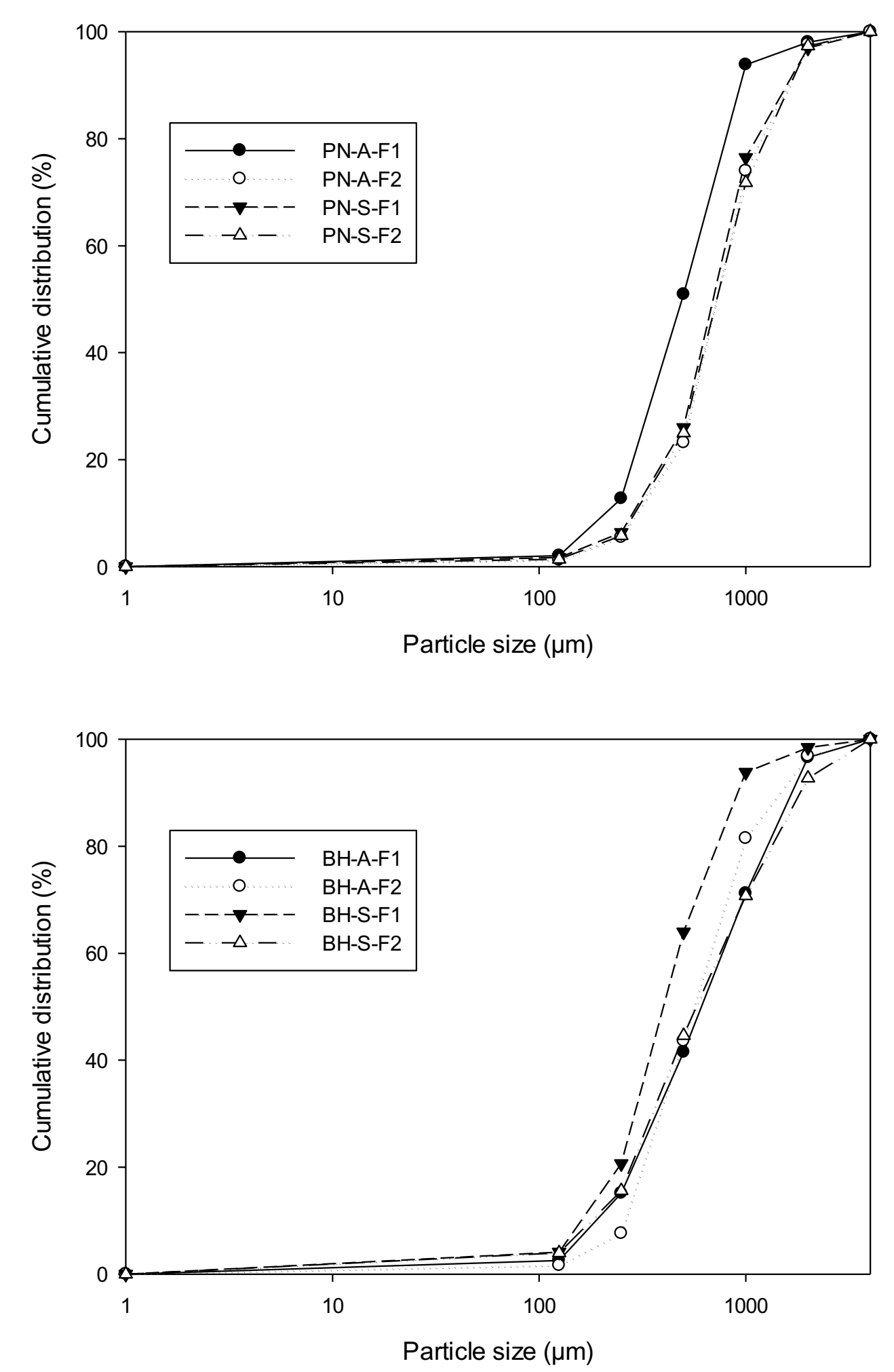

Fig. 3 Particle size distributions of beech wood dust—by sieve analysis method as a function of both drying method and feed per tooth
Although no statistically significant differences in fracture toughness values were shown, these properties noticeably affected the differences values of the estimated shear angle for slow feed rates. The higher values of shear angle and lower values of fracture toughness can be the reason for the noticeably higher proportion of smaller sawdust particles obtained (Fig. 3) while sawing the beech wood dried in the experimental kiln with a lower feed speed. Moreover, for both species pine (Pinus sylvestris L) and beech (Fagus sylvatica L.), a decrease in fracture toughness as a result of 
Table 2 Statistics of particle size distributions obtained by the sieve analysis method

\begin{tabular}{lll}
\hline Sample & Arithmetic mean diameter & SD \\
\hline PN-A-F1 & 550.3 & 201.7 \\
PN-A-F2 & 812.0 & 238.0 \\
PN-S-F1 & 770.1 & 251.1 \\
PN-S-F2 & 816.2 & 249.4 \\
BH-A-F1 & 729.5 & 285.4 \\
BH-A-F2 & 663.2 & 256.9 \\
BH-S-F1 & 489.9 & 196.5 \\
BH-S-F2 & 661.0 & 351.8 \\
\hline
\end{tabular}

accelerated drying in the kiln was also observed (Orlowski and Wierzbowski 2010; Chuchala et al. 2017). This phenomenon may indicate greater fragility of the processed material, and thus the appearance of finer particles in the tested chips.

Nonetheless, due to the large standard deviation values for all mean particle sizes, all these differences are not statistically significant. Therefore, sieve analysis of sawdust could only be a method of a preliminary evaluation of sawdust in terms of the content of the finest particles that may pose a health risk to woodworking employees. Respirable fraction particles have a much smaller size than the mean diameters measured by sieve analysis. Consequently, methods making it possible to measure the content of particles of this size should be used to evaluate the particle size distribution of sawdust in this regard.
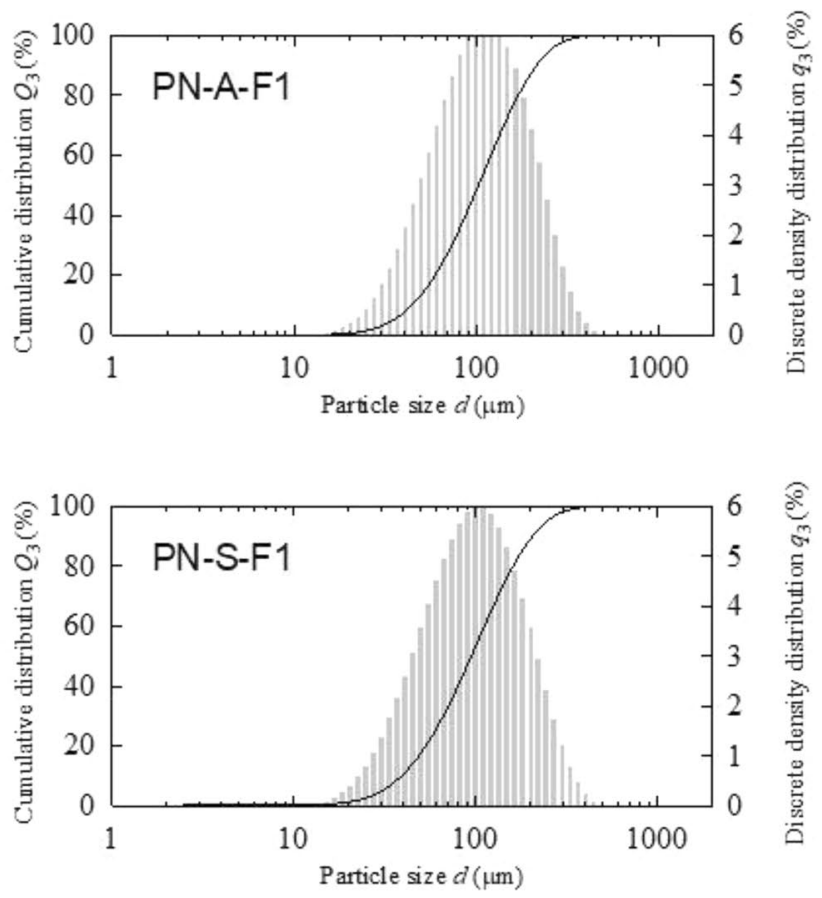

In this study, the particles collected $<125 \mu \mathrm{m}$ were subjected to laser diffraction analysis. The particle size distributions of this fraction obtained in this way are shown in Figs. 4 and 5. Similarly to the results of the sieve analysis, the mean particle diameter and standard deviation were also calculated for the sawdust fraction $<125 \mu \mathrm{m}$ (Table 3 ). These values also indicate that beech sawdust is slightly finer than pine sawdust. Furthermore, the lower feed per tooth $0.105 \mathrm{~mm}$ causes the creation of finer sawdust (except for air-dried pine wood). However, due to the high standard deviation values, the differences between the mean values are not statistically significant. Nevertheless, due to the large range of the laser particle size, it is possible to determine the content of particles, which due to their small sizes can penetrate deeply into the human respiratory system.

The results of the content calculation of the finest dust particles taking into account the fractions with characteristic dimensions of $0.08-2.5 \mu \mathrm{m}, 2.5-4 \mu \mathrm{m}$ and $4-10 \mu \mathrm{m}$ are shown in Fig. 6. The content of these fractions of dust particles in pine sawdust is negligible. The total content of these dust fractions is less than $0.01 \%$ except for sawdust created from the pine wood dried in the modified air-drying process sawn at a feed per tooth of $0.105 \mathrm{~mm}$, where it is about $0.04 \%$ of the total mass of sawdust. It is different for beech wood sawdust, where the content of these fine particles is much higher and depends on both the feed per tooth and the drying method. The total content of particles with sizes below $10 \mu \mathrm{m}$ for wood dried in the modified air method and a feed per tooth of $0.202 \mathrm{~mm}$ is around $0.07 \%$, and a feed
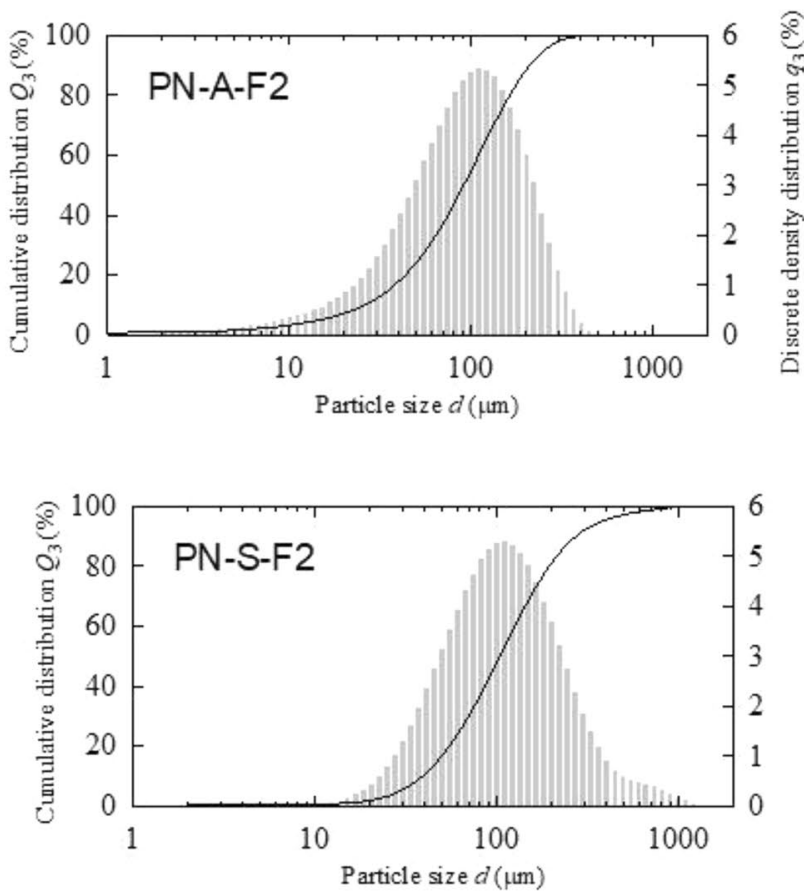

Fig. 4 Particle size distributions of pine wood dust fraction $<125 \mu \mathrm{m}$ as a function of both drying method and feed per tooth 

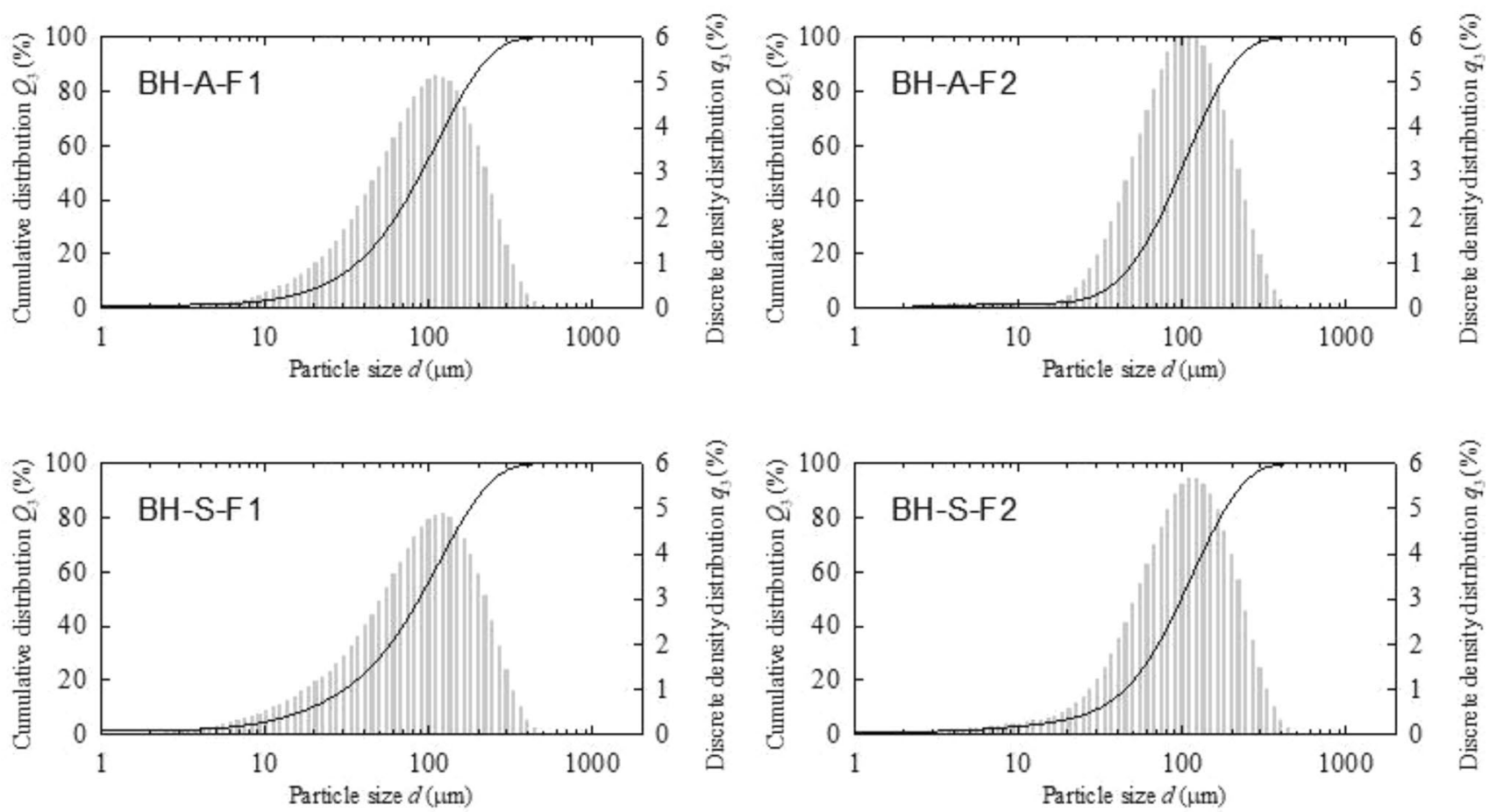

Fig. 5 Particle size distributions of beech wood dust fraction $<125 \mu \mathrm{m}$ as a function of both drying method and feed per tooth

Table 3 Statistics of particle size distributions of wood dusts fraction $<125 \mu \mathrm{m}$

\begin{tabular}{llr}
\hline Sample & Arithmetic mean diameter & \multicolumn{1}{c}{ SD } \\
\hline PN-A-F1 & 117.51 & 68.61 \\
PN-A-F2 & 106.16 & 74.17 \\
PN-S-F1 & 110.36 & 68.84 \\
PN-S-F2 & 140.51 & 132.85 \\
BH-A-F1 & 106.69 & 75.84 \\
BH-A-F2 & 111.08 & 67.44 \\
BH-S-F1 & 101.55 & 80.59 \\
BH-S-F2 & 113.29 & 74.66 \\
\hline
\end{tabular}

per tooth of $0.105 \mathrm{~mm}$ adequately equals to $0.25 \%$. However, for wood dried in the warm air-steam mixture, the content of these dust particles is already more than 4.5 times. Nearly $0.33 \%$ of particles with sizes below $10 \mu \mathrm{m}$ were found in sawdust from sawing of such beech wood. The formation of such small particles of beech wood during the cutting process introduces a significant risk of these particles getting into the air in the space where humans are (operators of machine tools). These particles, when dispersed in air, may pose a potential hazard to occupational health and safety (Aro et al. 2019; Beljo-Lučić et al. 2011). This threat is exacerbated by the carcinogenicity of this wood species.

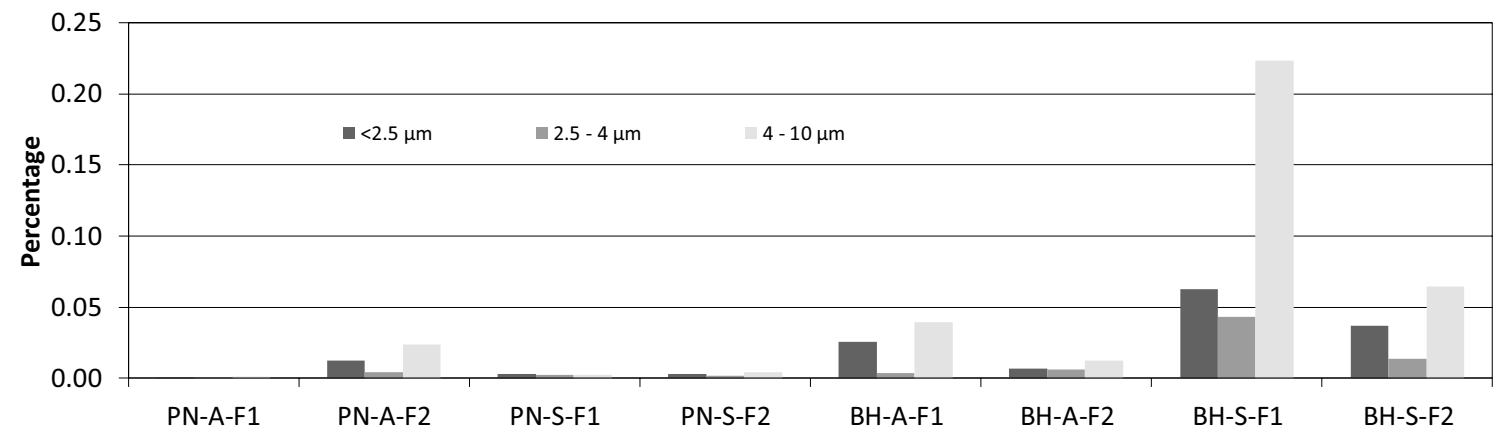

Fig. 6 Content of the finest particles $m$ in the total mass of sawdust 


\section{Conclusion}

Based on these studies, it can be concluded that:

- the drying mode does not affect the mean particle diameter of sawdust created in the sawing process of pine and beech wood on a PRW-15M sash gang saw;

- the finer dust was created in the sawing process carried out with a feed per tooth of $0.202 \mathrm{~mm}$; nevertheless, the difference is insignificant;

- the beech wood sawdust was also finer. However, in this case the difference between wood species also was insignificant;

- the content of the finest dust particles with size $<10 \mu \mathrm{m}$ was many times larger in the beech wood sawdust than in the pine wood sawdust. The highest content was found in the sawdust created in sawing wood dried in the warm air-steam mixture drying process using the feed per tooth rate of $0.202 \mathrm{~mm}$.

The particle size analyses of sawdust from pine and beech wood showed that the sawing of beech wood dried in warm air-steam mixture can be a source of very fine dust particles, especially when the sawing is carried out at a low feed per tooth rate.

Funding The authors gratefully acknowledge the Ministry of Science and Higher Education, Poland for funding the maintenance of scientific and research equipment - PRW-15M frame saw (decision no. 21/E359/SPUB/SP/2019) and for financial support within the grant no. 005/ RID/2018/19. The financial support of the National Science Centre, Poland within the project MINIATURA 2 no. 2018/02/X/ST8/03399 is gratefully acknowledged.

\section{Compliance with ethical standards}

Conflict of interest The authors declare that they have no conflict of interest.

Open Access This article is licensed under a Creative Commons Attribution 4.0 International License, which permits use, sharing, adaptation, distribution and reproduction in any medium or format, as long as you give appropriate credit to the original author(s) and the source, provide a link to the Creative Commons licence, and indicate if changes were made. The images or other third party material in this article are included in the article's Creative Commons licence, unless indicated otherwise in a credit line to the material. If material is not included in the article's Creative Commons licence and your intended use is not permitted by statutory regulation or exceeds the permitted use, you will need to obtain permission directly from the copyright holder. To view a copy of this licence, visit http://creativecommons.org/licenses/by/4.0/.

\section{References}

Aro MD, Geerts SM, French S, Cai M (2019) Particle size analysis of airborne wood dust produced from sawing thermally modified wood. Eur J Wood Prod 77(2):211-218. https://doi.org/10.1007/ s00107-019-01385-Z

Baran S, Teul I (2007) Wood dust: An occupational hazard which increases the risk of respiratory disease. J Physiol Pharmacol 58(Suppl 5):43-50

Baranski J, Klement I, Vilkovská T, Konopka A (2017) High temperature drying process of Beech Wood (Fagus sylvatica L.) with different zones of sapwood and red false heartwood. BioRes 12(1):1861-1870. https://doi.org/10.15376/biore s.12.1.1861-1870

Baranski J (2018) Moisture content during and after high- and normal-temperature drying processes of wood. Dry Technol 36(6):751-761. https://doi.org/10.1080/07373937.2017.13553 19

Beljo-Lučić R, Čavlović AO, Jug M (2011) Definitions and relation of airborne wood dust fractions. In: 4th International Scientific Conference-WOODWORKING TECHNIQUES, September 7-10, 2011, Prague, Czech Republic, 25-32

Bejlo-Lučić R, Čavlović A, Antonović A, Vujasinović E, Šimičić I (2005) Properties of chipped wood generated during mechanical wood processing. Drvna Ind 56(1):11-19

Chuchala D, Orlowski KA, Barański J, Ochrymiuk T (2017) Cutting power estimation of the bandsawing process of beech wood (Fagus sylvatica L.) dried in three operating modes. Ann WULS-SGGW For Wood Technol 99:75-80

Chuchala D, Ochrymiuk T, Orlowski KA, Lackowski M, Taube P (2020) Predicting cutting power for band sawing process of pine and beech wood dried with the use of four different methods. BioRes 15(1):1844-1860. https://doi.org/10.15376/biore s.15.1.1844-1860

Dzurenda L, Očkajová A (2003) Dimensional analysis of spruce wood dust. pine and oak from the plane grinding process. In: Proceedings of the Scientific Conference Machining and Joining of Wood. Zvolen. 53-57 (in Slovak)

Dzurenda L, Kučerka M (2005) Change in structure and aeromechanical characteristics of wet spruce sawdust in the process of drying. Ann WULS-SGGW Forestry Wood Technol 56:230-236

Dzurenda L, Wasielewski R, Orlowski K (2006) Granulometric analysis of dry sawdust from the sawing process on the frame sawing machine PRW15M. Acta Fac Xylologiae 48(2):51-57

Dzurenda L, Orłowski KA, Grzeskiewicz M (2010) Effect of thermal modification of Oak wood on sawdust granularity. Drvna Ind 61(2):89-94

Dzurenda L, Orlowski K (2011) The effect of thermal modification of ash wood on granularity and homogeneity of sawdust in the sawing process on a sash gang saw PRW 15-M in view of its technological usefulness. Drewno 54(186):27-37

Hlásková L, Rogoziński T, Dolny S, Kopecký Z, Jedinak M (2015) Content of respirable and inhalable fractions in dust created while sawing beech wood and its modifications. Drewno 58(194):135-146. https://doi.org/10.12841/ wood.1644-3985.096.11

Hlásková L, Rogoziński T, Kopecký Z (2016) Influence of feed speed on the content of fine dust during cutting of two-side-laminated particleboards. Drvna Ind 67(1): 9-15. https://doi.org/10.5552/ drind.2016.1417

IARC (2012) Arsenic metals fibres and dusts: IARC monographs on the evaluation of carcinogenic risks to humans. IARC, Lyon, France

Jacobsen G, Schaumburg I, Sigsgaard T, Schlünssen V (2010) Nonmalignant respiratory diseases and occupational exposure to wood dust. Part II. Dry wood industry. Ann Agr Env Med 17(1):29-44 
Klement I, Vilkovská T, Baranski J, Konopka A (2018) The impact of drying and steaming processes on surface color changes of tension and normal beech wood. Dry Technol 37:1490-1497. https://doi. org/10.1080/07373937.2018.1509219

Kminiak R, Banski A (2019) Granulometric analysis of chips from Beech. Oak and Spruce woodturning blanks produced in the milling process using 5-axial CNC machining center. Acta Fac Xylologiae 61(1):75-82. https://doi.org/10.17423/afx.2019.61.1.07

Kminiak R, Dzurenda L (2019) Impact of sycamore maple thermal treatment on a granulometric composition of chips obtained due to processing on a CNC machining mentre. Sustainability 11(3):718. https://doi.org/10.3390/su11030718

Kučerka M, Očkajová A (2018) ThermoWood and granularity of abrasive wood dust. Acta Fac Xylologiae 60(2):43-51. https:// doi.org/10.17423/afx.2018.60.2.04

Mračková E, Krišták L, Kučerka M, Gaff M, Gajtanska M (2016) Creation of wood dust during wood processing: size analysis, dust separation and occupational health. BioRes 11(1):209-222. https ://doi.org/10.15376/biores.11.1.209-222

Očkajová A, Bejlo-Lučić R, Čavlović A, Terenòvá J (2006) Reduction of dustiness in sawing wood by universal circular saw. Drvna Industrija 57(3):119-126

Očkajová A, Stebila J, Rybakowski M, Rogoziński T, Mračková E, Krišták L, L'uptáková J (2014) The granularity of dust particles when sanding wood and wood-based materials. Adv Mater Res 1001:432-437

Očkajová A, Kučerka M, Banski A, Rogoziński T (2016) Factors affecting the granularity of wood dust particles. Chip Chipless Woodwork Process 10(1):137-144

Očkajová A, Kučerka M (2017) Granular analysis of sand oak wood particles (in Slovak). Acta Fac Tech 22(2):93-101

Očkajová A, Kučerka M, Krišták L, Igaz R (2018) Granulometric analysis of sanding dust from selected wood species. BioRes 13(4):7481-7495. https://doi.org/10.15376/biores.13.4.7481-7495

Očkajová A, Kučerka M, Kminiak R, Rogoziński T (2020) Granulometric composition of chips and dust produced from the process of working thermally modified wood. Acta Fac Xylologiae 62(1):103-111. https://doi.org/10.17423/afx.2020.62.1.09

Orlowski KA, Wierzbowski MA (2010) Fracture toughness and shear yield strength determination of steam kiln-dried wood. In: Proceedings 'The Future of Quality Control for Wood \& Wood Products', 4-7th May 2010, Edinburgh. The Final Conference of COST Action E53. http://www.timberdry.net/downloads/EDGWorkshop-Edinburgh/Edinburgh-Presentation/18.pdf . Accessed 27 June 2020
Orlowski KA, Chuchala D, Muzinski T, Baranski J, Banski A, Rogoziński T (2019) The effect of wood drying method on the granularity of sawdust obtained during the sawing process using the frame sawing machine. Acta Fac Xylologiae Zvolen 61(1):8392. https://doi.org/10.17423/afx.2019.61.1.08

Pakulska D, Soćko R, Szymczak W (2017) Wood dust - inhalable fraction. Documentation of proposed values of occupational exposure limits (OELs) (in Polish). Podstawy i Metody Oceny Środowiska Pracy 3(93):17-93. https://doi.org/10.5604/01.3001.0010.4272

Pałubicki B, Rogoziński T (2016) Efficiency of chips removal during CNC machining of particleboard. Wood Res 61(5):811-818

Piernik M, Rogoziński T, Krauss A, Pinkowski G (2019) The influence of the thermal modification of pine (Pinus sylvestris L.) wood on the creation fine dust particles in plane milling. J Occup Health 61(6):481-488. https://doi.org/10.1002/1348-9585.12075

Rogoziński T, Očkajová A (2013) Comparison of two methods for granularity determination of wood dust particles. Ann WULSSGGW For Wood Technol 81:197-202

Rogoziński T, Wilkowski J, Górski J, Czarniak P, Podziewski P, Szymanowski K (2015) Dust creation in CNC drilling of wood composites. Biores 10(2):3657-3665. https://doi.org/10.15376/biore s.10.2.3657-3665

Rogoziński T, Wilkowski J, Górski J, Szymanowski K, Podziewski P, Czarniak P (2017) Fine particles content in dust created in CNC milling of selected wood composites. Wood Fiber Sci 49(4):461-469

Tong R, Cheng M, Zhang L, Liu M, Yang X, Li X, Yin W (2018) The construction dust-induced occupational health risk using Monte-Carlo simulation. J Clean Prod 184:598-608. https://doi. org/10.1016/j.jclepro.2018.02.286

Wasielewski R, Orlowski K (2002) Hybrid dynamically balanced saw frame drive. Holz Roh Werkst 60(3):202-206. https://doi. org/10.1007/s00107-002-0290-4

Wilnhammer M, Wittkopf S, Richter K, Weber-Blaschke G (2017) The impact of a new emission control act on particulate matter emissions from residential wood energy use in Bavaria. Germany. J Clean Prod 145:134-141. https://doi.org/10.1016/j.jclep ro.2017.01.039

Publisher's Note Springer Nature remains neutral with regard to jurisdictional claims in published maps and institutional affiliations 